\title{
The Sociological Review of the Role of the National Agency of Drug and Food Control Pekanbaru on the Distribution of School Children Food and Snacks Containing Harmful Substances in Pekanbaru
}

\author{
Ahmad Fuadi ${ }^{1}$, Rosyidi Hamzah ${ }^{2 *}$, Admiral ${ }^{3}$, Fadhel Arjuna Adinda ${ }^{4}$ \\ ${ }^{1}$ Postgraduate Department of Law Science, Universitas Islam Riau, Indonesia \\ ${ }^{2 *}$ Postgraduate Department of Law Science, Universitas Islam Riau, Indonesia \\ ${ }^{3}$ Postgraduate Department of Law Science, Universitas Islam Riau, Indonesia \\ ${ }^{4}$ Postgraduate Department of Law Science, Universitas Islam Riau, Indonesia \\ *rosyidihamzah@law.uir.ac.id
}

\begin{abstract}
Food is basically primary human need and right. Food supply is not only about quantity but also safety. The aspect of food safety is very important since it is closely related to public health. The quality of a nation depends on its food. The role of the National Agency of Drug and Food Control (NADFC) (Indonesian: Badan PengawasObat dan Makanan/BPOM) is to control or supervise the distribution of drugs and food in the market and provide guidance to business actors. The supervision carried out by NADFC on food products indirectly plays a role in protecting consumers from food products that are not suiTABLE for consumption. The gap between law in book and law in action in the distribution of food and snacks containing dangerous substances in elementary schools in Pekanbaru must be resolved immediately. One of the institutions that also conducts supervision on the distribution of food is NADFC Pekanbaru. To optimize this supervisory function, improvements need to be made in terms of substance (law), structure (organization), and legal culture in society. In order to make the law work more effectively, there must be synergy of the substance, structure, and culture of law.
\end{abstract}

Keywords: Sociological, Drug, Food Control, School Children

\section{INTRODUCTION}

Food is the most substantial basic human need and its fulfillment is part of the human rights of every Indonesian people. It is a must that food is always available in sufficient, safe, quality, nutritious, and varied at a price that is affordable to the purchasing power of the people, and in accordance with the community's religion, belief and culture. In order to achieve all those mentioned, it is necessary to establish a food system that provides protection for those who produce and consume food [1].

Food is basically primary human need and right. Food supply is not only about quantity but also safety. The aspect of food safety is very important since it is closely related to public health [2]. The quality of a nation depends on its food. Accordingly, the state is present in ensuring that the food consumed by the society is safe for health and highly nutritious. People as consumers have the right to safe, healthy and nutritious food. Food safety and quality contribute to the quality of Human Resources and the competitiveness of the nation. The National
Agency of Drug and Food Control (NADFC) (Indonesian: Badan PengawasObat dan Makanan/BPOM) is an institution in Indonesia whose function is to oversee the distribution of drugs and food. NADFC is a non-departmental institution formed by the government that is directly responsible to the President in carrying out its duties.Based on Article 2 of Presidential Regulation on NADFC, the main duty of NADFC is to carry out government duties in the field of drug and food control in accordance with statutory provisions. Drugs and food as intended consist of drugs, medicinal ingredients, narcotics, psychotropic substances, precursors, addictive substances, traditional medicines, health supplements, cosmetics and processed food [3].

Furthermore, the role of NADFC is to supervise the distribution of drugs and food in the market and provide guidance to business actors. The supervision carried out by NADFC on food products indirectly plays a role in protecting consumers from food products that are not suiTABLE for 
consumption. The supervision of food products carried out by NADFC indicates that NADFC is involved in safeguarding consumer rights; maintaining consumer security and safety, (article 4 letter a of Law Number 8 of 1999 on consumer protection). Even though there is a consumer protection agency and a food product control agency (NADFC), there are still business actors who commit fraud by manipulating the products they will sell. The manipulations include selling products that have expired, selling products that use Food Additives that are prohibited from being used, selling recycled products that are no longer suiTABLE for consumption, and selling products that do not meet the health standards set by the government.

Advances in technology and science change the pattern of food and drug production. The distribution of School Children Food Snacks (Indonesian: Panganan dan Jajanan Anak Sekolah/PJAS) containing dangerous substances in Pekanbaru needs serious attention. Children have a weakness in buying food and snacks at school since they usually only see the external appearance of these foods without knowing whether or not there are harmful substances contained. This is because children still lack of knowledge of harmful substances in food. There are basically 3 factors causing snack business actors to use harmful food additives including ignorance factor, deliberate factor, and people's purchasing power factor. The role of NADFC Pekanbaru in the circulation of PJAS containing harmful substances in Pekanbaru has not been maximally implemented due to limited authority of NADFC in taking action against business actors who violate the law. Thus, there is a need for fundamental changes to the laws and regulations governing the authority of NADFC to take action against perpetrators of violations of the distribution of food and drugs in a criminal, administrative and civil manner The discovery of toxic substances in food proves the weakness of supervision carried out on processed food vendors. Strict legal sanctions have been made for food and beverage sellers who do not meet or do not comply with the standards required by Law Number 8 of 1999 on Consumer Protection; a sentence of 5 years in prison and a fine of IDR 2,000,000,000 (two billion rupiah). In fact, sellers still sell food and drinks containing harmful substances to consumers. On the other hand, NADFC has very limited authority to take action against perpetrators who sell snacks containing harmful food additives.

Consumers have the right to security and safety in using the goods or services they obtain so that they can avoid harm (physical or psychological) in the consumption of a particular product. It is important to convey correct information to consumers about a product in order to make sure that consumers are not mistaken for the description of a particular product. It can be conducted in the form of representations, warnings, and instructions[4]. More importantly, law and society are two things that cannot be separated. Society needs law to guarantee regularity and tranquility, while law also needs society as the application field of norms that have been agreed upon by society. Thus, there is a phrase Ibisocietas ubi ius which means that where there is society, there is law. Law is born from the interactions that exist in society. The society's response to existing values can be seen from how the law is in practice (law in action). In practice, the law can change people's lives in accordance with the objectives of the law (law as a tool of social engineering). On the other hand, the law that has been applied cannot change the irregular pattern of people's lives because of the gap between the values applied in the law and the values that exist in society. This is also caused by the culture of the people themselves that do not obey the laws that have been applied.

Accordingly, the dynamics of society related to this law must be resolved. The rise of food and snacks sellers for school children in the vicinity of elementary schools in Pekanbaru is a reflection of the failure to implement laws relating to society protection in the food sector. The existence of gaps between law in book and law in action needs to be analyzed in terms of legal sociology to get a perfect picture of how law works in society. One of the duties of sociology of law is to reveal the causes of the imbalance between the desired society order and society order in reality[5].

\section{RESEARCH METHODS}

In terms of its type, this research is classified as an observational research which is carried out by means of a survey; direct research to the research location using data collection tools in the form of interviews and questionnaires. Moreover, based on its nature, this research is analytical descriptive, which means that the research is intended to provide a detailed, clear and systematic description of the main research problems. The object of this research was about the sociological review of the role of NADFC for elementary school students on ready-to-eat food consumed in the form of food or snacks containing addictive/dangerous substances sold freely in schools.

In accordance with the research title, this research was conducted at NADFC Riau Province and Elementary Schools. The reason for choosing the title was because in these places, the researchers obtained information related to the topic and issues 
of this research. In addition, the population and respondents of the study were street vendors in the elementary school environment in Pekanbaru City and the Head of the National Agency of Drug and Food Control (NADFC) Pekanbaru City. Data were collected using interviews and questionnaires.

\section{RESULT AND DISCUSSION}

In a society, no single system of social control can function perfectly. Although the forms and frequency of non-confirmatory emergence in each society differ widely, unfortunately, there are always some people in society who do not behave as expected since not all societies apply values and fully comply with rules, laws, or principles[6]. Law is not a neutral phenomenon, which is merely a product of free human invention, but the law is very closely intertwined with social problems and developments. Law can be related to social factors in two ways. Basically, the law can be explained with the help of social factors. On the other hand, social phenomenon can be explained by law.

Snacks are ready-to-eat food and drinks prepared or sold by sellers or hawkers at road junctions and other similar places. The characteristics of healthy snacks include:

- Free from the disturbance of animals carrying germs

- $\quad$ Free from dirt and dust

- Foods that are fried, boiled and steamed using sufficient heat

- Served using a clean base and washed first with clean water

- Taken using tools (spoons, forks).

- Food cleaning tools such as rags are clean

Conversely, the characteristics of unhealthy snacks are :

- Brightly colored

- Smells unhealthy

- Very chewy

- Food stored in open areas, which is prone to dust, dirt and insect exposure.

School children have a high risk of the effects of the snacks they consume every day. School snacks that contain dangerous ingredients are mostly found in ice, colored syrups, jelly, and meatballs. Snacks and food are usually contaminated with bacteria and chemicals such as dyes, artificial sweeteners, borax, rhodamine B, and formalin. It is crucial to educate children so that they can distinguish between healthy foods and dangerous foods. The education can be conducted by introducing foods that are safe from biological, chemical and other hazards. Another form of education is to provide direction to elementary school students to buy safe food in a clean place, well-cooked food, and food sold by healthy and clean sellers. It is also important to emphasize elementary school students to read labels carefully, taking into account the name and address of the producer, the ingredients used, and the expiration date

The role of NADFC Pekanbaru in the distribution of PJAS containing harmful substances in Pekanbaru has not been maximally implemented due to limited authority of NADFC in taking action against business actors who violate the law. The authority to conduct investigations of the Civil Servant Investigator of NADFC are very limited and, in practice, they must always coordinate with the relevant law enforcement officials. Several laws and regulations explicitly state the prohibitions and sanctions on food production. Thus, there is a need for fundamental changes to the laws and regulations governing the authority of NADFC to take action against perpetrators of violations of the distribution of food and drugs in a criminal, administrative and civil manner [7].

Moreover, to minimize violations of the circulation of dangerous substances in snacks sold around the elementary school environment, consistent and continuous cooperation is also needed between NADFC and other related institutions such as the Health Office, Industry and Trade Service, the Police, the Attorney General's Office and other related parties to anticipate the occurrence of these violations. There must be good cooperation between related parties such as the Health Office, the Industry and Trade Office, the Education Office and other parties to maximize supervision of the distribution of harmful food additives in school children's food and snacks sold in the school environment in Pekanbaru. School canteens must be monitored by the Principal. Meanwhile, street vendors outside the school fence should be immediately followed up both administratively and criminally.

Importantly, the distribution of illegal imported food sold by MSME traders in Pekanbaru needs to be resolved properly by NADFC Pekanbaru. However, the supervision carried out by NADFC on the distribution of illegal imported food is still not effective. There are still many shortcomings made by NADFC Pekanbaru, such as incomplete facilities and infrastructure, lack of qualified human resources and slow handling of complaints from the society. If this case is ignored, the health of the children in Pekanbaru will be threatened since this food, with cheap price, is favored by children.

The ineffectiveness of law enforcement against business actors selling food and snacks for school children containing dangerous substances in Pekanbaru demonstrates the ineffectiveness of the legal system that protects the society from deviant behavior by business actors and weak supervision 
from related parties. The law is not a detergent, which can wash itself. The law can never act to realize what is written without human intervention. Thieves can only be punished if the police take action. Corruptors can only be tried and punished if the police, prosecutors and judges cooperate with each other. The law is only a pile of paper if humans do nothing to implement. The law becomes useless if humans do not intervene with passion (compassion, empathy, determination) to provide justice for the people.

Furthermore, law enforcement is a process to bring legal desires into reality. The legal desires here are the thoughts of the legislature formulated in the legal regulations. The need to talk about the law enforcement process reaches into legal action. Mawardi said, "I do not register the mini meatballs I sell to NADFC or the Health Office. The important thing is that the meatballs are sold and meet the consumer tastes. I have also never been given any socialization from any institution. Additionally, Herman admitted that the soft drink he was selling had not been registered to the Health Office or NADFC since the most important thing for him was that it tasted good and its price was affordable for elementary school children.

The results of the interview indicate that business actors are still weak in legal awareness to comply with existing regulations. In reality, the source of the strength that binds the law is legal awareness. Legal awareness is closely related to law, while law is a cultural product. Culture is a 'blue print of behavior' which provides guidelines about what to do and what not to do. Thus, culture includes a system of goals and values. Law is a reflection of the values that exist in society. Embedding legal awareness means instilling cultural values. These cultural values can be achieved by education. Therefore, after knowing the possible causes for the decline in legal awareness of society, the main, effective and efficient effort to increase and develop it is through education[8]. To protect the society in buying food and snacks, especially children, the State must be present to oversee the distribution of food containing dangerous food additives. NADFC Pekanbaru has the function and authority to oversee the distribution of drugs and food. However, in its application, there are many obstacles to perform its authority, one of which is that NADFC, does not have a legal basis. The function of law is to provide clarity regarding the status of people and goods in society. The Legal Basis of NADFC is only a Presidential Decree on Non-Departmental Government Institutions and does not yet have a specific law. NADFC is in dire need of legislation because its food and drug control duties are of a national strategic nature. According to
Aristotle, the existence of clear laws will direct humans to moral values.

The enactment of a law that will strengthen the role of NADFC in overseeing the distribution of food is expected to be a means of changing people's habits. Law is useful as a tool for reform in society (law as a tool of social engineering). The law used as a means of social engineering can be in the form of statutory regulations. It has a mission to prevent bad behavior, inviting people to the path of truth according to what Allah wants as the owner of absolute truth. As an attempt to make sure that the regulations aimed at reforming can be carried out properly, laws should be formed in accordance with what constitutes the core values in accordance with the values that live in the community. Accordingly, it reflects the values that live in society. If it is done the opposite, the regulations cannot be implemented and there will be challenges. There is a close relationship between law on the one hand and sociocultural values on the other. The close relationship between law and socio-cultural values of society shows that good law is law that reflects the values that live in society[9].

Making and formulating policies is not a simple process, especially state policies. There are many factors and forces that will influence the process. However, state policies must address the interests of the people as a whole in an effort to meet the people's needs and welfare. Therefore, formulating state policy must pay close attention to the values that come from the beliefs, aspirations and needs of the society to maintain and prosper the lives of the people. These values, together with the norms and goals of society, become the value system of a society.

Something is considered valuable if it has quality and will function as a driving force as well as a limit for human behavior. These values can take the form of needs, wants and demands from society that needs to be fulfilled by state policy makers. However, in a society, there are many values, which can be different or have in common with one another. Accordingly, state policy is basically the decision to choose the best value from the many values that exist in society. The best value chosen is the value in accordance with the interests of the society. Albert mentioned the following legal functions in the community:

- governance function

- $\quad$ resource distribution function

- $\quad$ safeguard function against community expectations

- $\quad$ conflict resolution function

- $\quad$ expression function of values and ideals in society 
To maximize the authority of NADFC Pekanbaru over the distribution of food and snacks for school children, changes must be made in the field of legal substance, legal structure and legal culture of the society. The weak legal basis of NADFC in conducting supervision, prosecution, investigation and imposing sanctions on business actors who commit violations causes business actors to always hide from NADFC Pekanbaru officers while conducting inspection.

In addition, there must be improvements in the structure including human resources, facilities and infrastructure. The supervision of the distribution of food and snacks in Riau province requires a lot of human resources. However, in fact, there is small number of human resources, so it is impossible to effectively supervise the distribution of food and snacks. The location of Riau province, which faces neighboring countries such as Malaysia and Singapore and directly faces the Malacca Strait, which is a means of international shipping transportation, must prioritize the control of distribution of drugs and food.

The last factor that makes law work effectively in society is the legal culture factor[10]. Even though the law and law enforcement officers are good, law enforcement cannot be effective if society likes to violate the law. Therefore, the legal culture of the society must be formed so that they understand the harmful substances contained in food. Importantly, business actors selling food and snacks for school children need to understand which substances are harmful to health. Business is indeed done for profit, but the business actors should not pursue profits at the expense of others.

\section{CONCLUSION}

Sociologically, the weak supervision carried out by NADFC on the distribution of drugs and snacks for school children containing dangerous substances in Pekanbaru is due to the weak legal basis of the authority of NADFC to carry out supervision, prosecution, and even sanctions. The second factor is regarding the structure related to human resources, that supervision over a very large area with a limited number of personnel inevitably results in ineffective supervision. The last factor is the legal culture of society. The purpose of the rules regarding food and snacks will not be implemented as long as society does not comply with the rules.

The gap between law in book and law in action in the distribution of food and snacks containing dangerous substances in elementary schools in Pekanbaru must be resolved immediately. One of the institutions that also conducts supervision on the distribution of food is NADFC Pekanbaru. To optimize this supervisory function, improvements need to be made in terms of substance (law), structure (organization), and legal culture in society. In order to make the law work more effectively, there must be synergy of the substance, structure, and culture of law.

\section{ACKNOWLEDGMENTS}

This study is Research Grants by The Ministry of Research and Technology/the National Agency for Research and Innovation of the Republic of Indonesia year 2020 and LPPM Universitas Islam Riau to support this research.

\section{REFERENCES}

[1] Penjelasan Konsideran Undang-Undang Nomor 18 Tahun 2012 Tentang Pangan. .

[2] Ida Bagus Gd Dianta Kurniawan \& R.A. Retno Murni, "Peran Badan Pengawas Obat dan Makanan Terhadap Peredaran Jajan Tradisional Pasar Berbahaya di Kota Denpasar," J. Kertha Semaya, vol. 8, no. 7, 2020.

[3] Siti Ajeng Putriani, "Restrukturasi Kewenangan BPOM dan Sistem Kooperatif Penanggulangan Peredaran Kosmetik Ilegal Secara Online," Legislatif, vol. 3, no. 2, 2020.

[4] Ahmadi Miru \& SutarmanYodo, Hukum Perlindungan Konsumen. Jakarta: Rajawali Press, 2014.

[5] Sabian Usman, Dasar-Dasar Sosiologi Hukum; Makna Dialog Antara Hukum dan Masyarakat. Yogyakarta: Pustaka Pelajar, 2009.

[6] Dominikus Rato, Sosiologi Hukum;Hukum Dalam Prespektif Kontruksi Sosial. Yogyakarta: Aswaja Presindo, 2016.

[7] B. A. Sidharta, Meuwissen Tentang Pengembanan Hukum, Ilmu Hukum, Teori Hukum dan Filsafat Hukum. Jakarta: Reflika Aditama, 2013.

[8] Ferry Angriawan \& Dyah Mutiarin, "Efektivitas Pengawasan Badan Pengawas Obat dan Makanan (BPOM) Terhadap Peredaran Makanan Impor Oleh Pedagang UMKM di Kota Pekanbaru," J. Gov. Civ. Soc., vol. 3, no. 1, 2019.

[9] Satjipto Rahardjo, "Membedah Hukum Progresif," Kompas, Jakarta, p. 111, 2008.

[10] Nurul Qamar, "Sosiologi Hukum (Sociology of Law)," Mitra Wacana Media, Jakarta, p. 168, 2016. 